\title{
The Arab Uprising and the Future of the Region
}

\section{Marwan Naser}

Department of International Development, The London School of Economics and Political Science LSE, Houghton Street, London, UK

*Corresponding author: Marwan Naser, Senior Research Fellow, Department of International Development, The London School of Economics and Political Science LSE, Houghton Street, London, UK, Tel: +44-7703 447233; E-mail: m.naser@lse.ac.uk

Rec date: Jun 30, 2014; Acc date: Jul 05, 2014; Pub date: Jul 12, 2014

Copyright: () 2014 Naser M. This is an open-access article distributed under the terms of the Creative Commons Attribution License, which permits unrestricted use, distribution, and reproduction in any medium, provided the original author and source are credited.

\begin{abstract}
This paper examines the political and economic vulnerabilities behind the Arab Uprising. Social justice and the provision of basic needs were at the top of the demands of the revolutions in Arab Word. Arab who took to the streets sought to topple a regime, which failed to deliver on political and economic reforms, and applied policies that increased poverty and inequality. Three years after the revolutions, the record of the Arab governments in meeting the socio-economic demands of the revolutions is mixed, at best. Not a few numbers of scholars have noted that the socio-economic policies of the current government do not differ from those of previous regimes with their bias towards the interests of the business class, failure to address social injustices, and dependency on western capital and International Financial Institutions' prescriptions. The question is: why hasn't the revolution achieved its goals? And why do the new governments continue to face crisis after crisis?
\end{abstract}

Keywords: Economic development; Political economy; Conflict and political transition

\section{Context}

The Arab state has attempted to institute reforms in various guises, but these have mostly ended up centralizing power, rather than dispersing it. Whether it is the Tanzimat reforms under Ottoman rule, nationalization of the 1960s or neo-liberal economic reforms of the 1980 s, they have all served as vehicles for refurbishing the state's power. It is useful to note that the revolution [1] did not end the reign of corruption and tyranny only, but it has also ended the era of Pharaoh and launched the freedom of societies; in addition to an end to the minority rule and the return of the masses in order to determine who is better to come to the helm of power, but why hasn't the revolution achieved its goals? And what next?

The Arab world [2] lies at the cusp of a new era. It is witnessing an unprecedented demographic transition resulting in one of the "largest youth cohorts" in its history [3]. The future of the Arab World crucially depends on whether it can convert this youthful transition into a productive transition. This requires Arab rulers to concede not just political space, but also greater economic access. Unless accompanied with a distribution of economic power, political reform alone will not be sufficient. Borrowing the conceptual formulation of Douglass North, what the Arab world needs today is an "open access order. The Arab state has typically created rents by restricting access to economic opportunities to a dominant coalition, and used these rents to sustain order.

The region's centralized and segmented administrative structures have restricted economic access and prevented the diffusion of economic rents through entrepreneurship and trade. Importantly, a segmented state apparatus has prevented the emergence of a business class that has direct stakes in more open regional markets. This has given rise to massive coordination failures, with the result that Arab governments and firms today are particularly deficient in capturing positive externalities and productive spillovers. This centralized bureaucratic rule has a long historical lineage, dating back to the Ottoman rule. The Ottoman Empire and its successor Arab states have been particularly efficient at promoting and guarding their autonomy from society. But, in this quest for absolutist control, bureaucracy has been turned into an irritant for the growth of bourgeoisie and regional economic integration $[4,5]$.

Through centralized economic control and restrictive economic barriers, Arab governments have erected a system of economic apartheid that systematically excludes people and firms at the margins. Although, the Middle East has modest levels of measured inequality by global comparisons, its central challenge is the inequality of access. Everywhere in the region there are strong advantages of incumbency. To create an open access order, a new governance paradigm needs to be imagined that brings people from the margins to the mainstream, offering them ladders for economic mobility-ladders that are defined by merit and competition, rather than (wasita) or connections. This requires that economic rewards are distributed through achievement rather than ascription, and that elite privileges are transformed into universal rights.

Arab economies [6] have long been greased through revenues from oil, aid and remittances. There is now a need to generate alternative revenue streams through trade and private sector development $[7,8]$ that can replace patronage with production. But it is inauspicious to talk about the necessity of economic reform at a time when the region's political climate is decidedly anti-business. The private sector is at once the most despised as well as the most desirable aspect of reform. Business in the Arab world is often comfortably embedded within the state, with the result that it invokes images of crony capitalism. At the same time, an estimated 100 million jobs need to be created in the MENA [9-11] region over the next decade or so. This employment challenge cannot be addressed without a strong private sector. And, without a strong private sector the human capital gains that the Arab world has achieved over time cannot be translated into solid productivity gains. 
An independent business sector will also serve a vital political function: it can generate a middle class that can serve as a powerful constituency for political reform. A robust private sector is thus both an economic and political imperative. But this requires a radically different business life. It requires a private sector that is open, competitive and can operate outside the royal circle. This can be achieved through a genuine infitah (economic opening) that dismantles entry barriers, replaces privilege with competition and ensures a decentralized and rules-based framework for decisionmaking. Viewed in this light, the struggle for a new Arab World will be won or lost in the private sector.

There is an overlap in the assessment of the revolution and the governance, whether it is influenced by media campaigns that have alienated people from the revolution and focused them on its downfalls instead, or the continuing crisis facing the new regimes in power that led people [12] to forget the achievements of the revolution.

It seems that decades of tyranny did not only destroy the present of these countries' politics and economy [13-15], but also spontaneously destroyed its future too. This was reflected in the majority being excluded from political life and its monopoly through one group or faction that was chosen by the President. As a result of this monopoly, other political groups did not have a chance to qualify for the state administration, nor take part in the advancement of the nation through its various institutions.

Given this background, it is obvious that the crisis of governance refers to several factors; the expected unrest that follows any revolution that has brought down a previous regime and establishes an alternative one, the heavy legacy left behind by the previous regimes due to the destruction of political, economic, social and state institutions, the unsuccessful leadership of the new regimes in power, the immature and poor performances by the opposition, the division of the components of the society as well as the rest of the political groups, the role of followers of the former regimes who are still in positions of power within the new regimes, and the impact of lawlessness on economic activities, and the external pressures mainly through negative media campaigns and economic blockade.

Most of these factors were expected, but what was disappointing is that the Islamic movements that came to power as a result of the revolutions did not live up to the expectations of its people. It has not exercised the required and expected transparency and has been slow and unsure in making key decisions. Recidivism promises has also exasperated the crisis of confidence. This has created a gap between the authority and the society, and had an impact on the revolution and its goals.

The arrival of Islamic movements to power is not surprising considering the years of oppression, marginalization, exclusions from political life and the fear to return to prison and exile. Being in power presented a safety net to the movements but at a hefty price. It would have been more worthy for these movements to focus on the principals and the success of the revolution, the democratic transition and the implementation of the demands of its people instead.

The rush to be in power has led the Islamic movements to make unrealistic electoral promises and expectations in all areas, including economic, political and social. This has forced these governments to look for foreign aid and loans as well as political support rather than focusing on putting their countries on the path of reform which is a strong blow to the principal of revolution that is against any regime where dependency represents one of its fundamental pillars. These movements have suffered a blow to their reputation, credibility and popularity.

To ensure a successful transition, all parties including the opposition and the governments in power must work together and participate in the crucial stage of building the state institutions based on strong fundamentals. This has not been the case in the Arab countries after the revolution where race for power rather than reform was the focus.

It has become apparent that if the Muslim Brotherhood were successful in running their parties, they have not had the same luck with running their countries. This is the essence of the current crisis that brought their countries to almost a political stand still. The current regimes seems to be stuck and don't know exactly where they are going amid adversity that is hitting them from every direction. To resolve this crisis will require a high degree of wisdom, courage and foresight. The revolution remains greater and deeper and far-reaching that the governance. The spirit of rebellion has reached countries where there hasn't been a change in power where voices are heard loud protesting oppression, corruption and social injustice.

There should be a distinction between two kinds of uprisings [16]; the Bustling Spring and the Silent Uprising. The first is publicly announced and can lead to the change of political systems. Whilst the Silent uprising expresses itself through the means of social communication, that are traded in quietly, and aims at reforming the regimes and the regulations and not necessarily to change them. This model is considered as reformist and not revolutionary.

In this context, many Gulf countries including Saudi Arabia have called for political reform through the release of detainees, and change to the way and methods the police use when dealing with frustrated citizens who are fed up and suffer from poverty, unemployment, financial and administrative corruption, declining interest in health and education. Such message is the most important and prominent in recent times in the region. The so called Arab spring [17] is an indication of the start of a historic change in the region, and special attention should be paid to its nation who is asking for social justice $[18,19]$, right of participation and inclusion in political life as well as defending its dignity.

From this angle, the Arab nation is facing a real dilemma that must be recognized and dealt with. At a time that the region is going through a radical change, instability and insecurity hangs on the Arab arena. When considering the scene there are only three projects, Economic development in Turkey, Political development in Iran and the settlement expansion in Israel. It does not stop at this point, because there are significant shifts occurring on the ground that suggest that the region is re-mapping, and could be on the way to what is new Sykes / Picot. The situation on the ground manifests the following observations;

Iraq is being divided after the demolition practiced by the American occupation. The Kurdish region has separated from Iraq and will soon achieve full independence; There is currently a strong call for the division of Iraq into three regions, one for the Kurds, the second for the Shiites, and the third for the Sunnites.

Evidences show that Syria is about to enter into the same stage, especially in light of the severe vibrations that hit the pillars of the regime, and the anticipation of the establishment of the State of Allauiites on the coast in the case of the fall of the president Assad. 
According to available information assets have been transferred to the Central Bank of Latakia, the airport and seaport being equipped for this purpose. However, President Assad has denied this during many interviews.

The fall of the Syrian regime will have a direct impact on the balance of power in Lebanon, notably a negative impact on Hezbollah, with this in mind the new situation in Syria will be antagonistic to Iran in particular. This may encourage the Suniites in Iraq to rise up against the regime. With this in mind Turkey has preceded it and reached a reconciliation agreement with the detainee Kurdish leader Abdullah Ojalan, to avoid the opportunity to use the Kurdish case fomenting unrest in Turkish territories.

Israel has apologized to Turkey and reinstated relations after ties were cut for three years; this seems to be in anticipation of the situation after the fall of the Syrian regime. There are many interrogation points about the status of Iran at some point after the fall of President Assad. And the potential of a military strike by Israel has not been ruled out yet.

South Sudan separated from the north, and calls for separation are strong in southern Yemen too. The Amazigh community in Morocco is showing some developments, which indicates that, the achievements in the cultural field, is in the process of transition to the process of political demands.

At the present there are confrontations between the Salafists and the Renaissance movement in Tunisia, tension in Egypt between the Salafists and the Muslim Brotherhood, and high tension between the last and the army, confrontation between the Salafists and the state in Algeria. These confrontations create tension between Liberalism and Islamic groups, which is sharp in Egypt, Tunisia, and to some extent in Morocco. In the absence of a prospect of any solution to the Palestinian cause in the foreseeable future, the prospect of a third intifada in the occupied territories is stronger than ever despite the geographical separation between the West Bank and Gaza.

Turkey has reached to understanding with Israel, and Tehran reached to understanding with Washington and questions arise about the prospects of final agreement between Tehran and Washington, especially as the current U.S. Secretary of State is in support of the idea. This agreement became more achievable after the departure of Mr. Ahmadi Nejad in the last presidential elections. So in the case of such agreement being achieved, the Arabs would be in a weaker position, if such agreement isn't reached at the detriment of their interests in any case.

There are many possible scenario cases, but the danger is that they take place without taking into consideration the interests of the Arab nation that could have catastrophic consequences in the region and its people. These indicators are sufficient to demonstrate that the map of the Arab world is being redrafted.

\section{References}

1. Bishara M (2012) The Invisible Arab: The Promise and Peril of the Arab Revolution.

2. Browers ML (2009) Political Ideology in the Arab World Accommodation and Transformation, Cambridge University Press, New York.

3. Tripp C (2007) A History of Iraq. Cambridge University Press, New York.

4. International Monetary Fund (2014) Regional Economic Outlook Update. Middle East and Central Asia, Washington, D.C.

5. Al-Atrash H, Yousef $\mathrm{T}$ (2000) Intra-Arab trade: Is it too little?. IMF Working Paper 10, International Monetary Fund, Washington, D.C.

6. Noland M, Pack H (2007) The Arab Economies in a Changing World.

7. Tarek M, Yousef (2004) Development, growth and policy reform in the Middle East and North Africa since 1950. J Econ Perspect 18: 91-115.

8. Industrial Development Report (2009) United Nations Industrial Development Organization. Oxford University Press, Oxford.

9. The World Bank (2008) MENA Economic Developments and Prospects: Regional Integration for Global Competitiveness. Washington, D.C.

10. Nugent JB, Yousef TM (2005) Does MENA defy gravity: How MENA has performed in its intraregional, EU and other trade. EUI Working Paper 2005/26, European University Institute, Florence.

11. International Crisis Group (2011) Popular Protest in North Africa and the Middle East (VI): The Syrian People's Slow-Motion Revolution. MENA Report 108, Brussels.

12. Tripp C (2013) The Power and the People: Paths of the Resistance in the Middle East. Cambridge University Press, New York.

13. Carapico S (1998) Civil Society in Yemen: The Political Economy of Activism in Modern Arabia. Cambridge University Press, New York.

14. Henry CM, Springborg R (2010) Globalization and the Politics of Development in the Middle East. Cambridge University Press, Cambridge.

15. Hudson M, (1998) Middle East Dilemma: The Politics and Economics of Integration. I. B. Tauris, London.

16. Pace M, Cavatorta F (2012) The Arab Uprisings in Theoretical Perspective - An Introduction. Mediterranean Politics 17: 125-138.

17. Bradley JR (2012) After the Arab Spring: How Islamists Hijacked the Middle East Revolts. Palgrave Macmillan, Newyork.

18. Halpern M (1963) The Politics of Social Change in the Middle East and North Africa. Princeton University Press, Princeton, NJ.

19. Heydemanm S (2000) War, Institutions, and Social Change in the Middle East. University of California Press, Berkeley. 